\title{
CONCEPT AND BASIC FEATURES OF THE ADMINISTRATIVE ACTIVITIY OF THE REVENUE AND DUTYAUTHORITIES EXECUTING CUSTOMS AFFAIRS
}

\section{Pryimachenko D. V.}

\section{INTRODUCTION}

Development of Ukraine as a social, legal state is directly related to increasing of public administration effectiveness, which is aimed at ensuring the sustainable development of society, timely identification, prevention and neutralization of real and potential threats to national interests in all areas of public life without exception.Ensuring an adequate level of national security of the state that meets the requirements of the present is one of the most important functions of the state. Public administration bodies are involved in the implementation of this function.Important role in ensuring national security belongs to the revenue and duties authorities, whose tasks and functions are aimed at protecting the national interests and rights of citizens and economic entities in the field of customs law regulation.

An analysis of the legal nature and content of the activity of the revenue and dutiesauthorities executing customs affairs should be carried out with taking into account the fact that this state organization was created in March 2013 as a result of reorganization of the State Customs Service of Ukraine and the resumption of its activity in $2018^{1}$. Currently, these authoritiesarean integral part of the structure of the State Customs Service of Ukraine (hereinafter referred to as the SFS of Ukraine) ${ }^{2}$.

1 Pro Ministerstvo dokhodiv i zboriv: Ukaz Prezydenta Ukrainy vid 18.03.2013 r. № 141/2013 Ofitsiinyi visnyk Ukrainy. 2013. № 22. St. 739. (In Ukrainian); Pro utvorennia Derzhavnoi fiskalnoi sluzhby Ukrainy: Postanova Kabinetu Ministriv Ukrainy vid 21 travnia 2014 r. № 160. Ofitsiinyi visnyk Ukrainy. 2014. № 46. St. 1213. (In Ukrainian).

2 Pro utvorennia Derzhavnoi fiskalnoi sluzhby Ukrainy: Postanova Kabinetu Ministriv Ukrainyvid 21 travnia 2014 r. № 160 Ofitsiinyi visnyk Ukrainy. 2014. № 46. St. 1213. (In Ukrainian); Pro utvorennia derzhavnoi podatkovoi sluzhby Ukrainy ta Derzhavnoimytnoi sluzhby Ukrainy: Postanova Kabinetu Ministriv Ukrainy vid 18 hrudnia 2018 r. № 1200. Ofitsiinyi visnyk Ukrainy. 2019. № 7. St. 208. (In Ukrainian). According to the current customs legislation (clauses 34-1, part 1, article 4 of the Customs Code of Ukraine), the bodies of revenue and duties are: the State Customs Service of Ukraine is the central executive body that provides for the formation and implementation of state tax and customs policy and its territorial divisions: customs and customs posts. Before the reorganization of the SFS of Ukraine in 2013, these authorities were called customs authorities.) 
In the process of carrying out their tasks and functions, the revenue and duties authorities actively use various in nature, forms and methods means and approaches of influence on public relations in order to regulate it. Among this set of means, we can single out, as they are defined in the legal literature, administrative legal means.The practical implementation of administrative remedies is carried out within the framework of activity, which has been called administrative in the legal literature ${ }^{3}$.

Of course, the fulfillment by the revenue and duties authorities of their functions involves the implementation, in addition to administrative, also other types of activity, for example, criminal procedural or financial and economic.However, in terms of volume and variety of carried out tasks, administrative activity occupies one of the most important places in the functioning of the revenue and duties authorities.Administrative activity is a type of state-governmental activity of executive bodies and covers a wide range of public relations, which are formed both within the system of the revenue and duties authorities, and beyond.

\section{Administrative activity: problems of definition and regulatory fixing}

Researching of the administrative activity concept and determining its features causes some difficulties, since the term «administrative activity» is not used in the current legislation, and in modern scientific literature is used in several different meanings, but is mostly identified with the term «public administration». ${ }^{4}$ In addition, the complexity of the study of this legal phenomenon is caused by the dynamic formation and development of the object and subject of the administrative activity, increasing the number of public administration bodies that carry it out. The definition "administrative activity" itself is not new to the science of administrative law. In scientific circulation this term was introduced by the Soviet administrative law researcher I.I. Yevtykhiyev, who defined administrative activity as the activity of executive and administrative bodies in the form of issuing acts of management and enforcement ${ }^{5}$.

In order to clarify the essence of the concept of administrative activity, it is necessary to analyze the most common definitions in the

\footnotetext{
${ }^{3}$ Pryimachenko D.V. Administratyvna diialnist mytnykhorhaniv: problemy teorii ta praktyky: Monohrafiia. Dnipropetrovsk: AMSU, 2007. 290 s. S. 9. (In Ukrainian).

${ }^{4}$ Petrov H.Y. Pooshchrenye v hosudarstvennom upravlenyy. Yaroslavl: Yzd-vo Yaroslavskoho un-ta, 1983. 219 s. S. 89. (In Russian).

${ }^{5}$ Pryimachenko D.V. Administratyvna diialnist mytnykhorhaniv: problemy teorii ta praktyky: Monohrafiia. Dnipropetrovsk: AMSU, 2007. 290 s. S. 174. (InUkrainian).
} 
administrative and legal literature. Thus, L.V. Koval means issuing of normative and individual acts under administrative activity ${ }^{6}$. However, the proposed definition, first, does not allow to determine the sphere of public activity in which it can be implemented and the entities authorized to carry out such activity, and secondly, it is related only to the issuance of legal acts that leaves outside such forms of activity as, for example, legal actions or organizational arrangements.

Some authors associate the existence of administrative activity with its normative fixing with the help of norms of administrative law ${ }^{7}$ or with the use of administrative and legal means by which it is carried out ${ }^{8}$. Existence of such a position can be explained by the influence of the continental system of administrative law, mainly France. For example, one of the most respected administrative law researchers, G. Vedel, argues that administrative activity (in other words, management) is a set of actions of the state and other public legal entities (departments, local collectives, communes) and public administrations that are not dependent on other than administrative regime owing to its special condition.However, talking about administrative regime, he is referring to the common law regime that regulates the activity of the state and public legal entities ${ }^{9}$. In other words, administrative activity is the activity of the state (state bodies) and other public legal entities regulated by the rules of general (administrative) law. This position is, in fact, correct, but it does not disclose the nature and content of this activity.

Some researchers define administrative activity as the activity of public authorities aimed at ensuring the protection of rights, public order and public safety, detection, termination and prevention of offenses ${ }^{10}$.

In this case, administrative activity is reduced to its understanding as a law enforcement activity carried out by various executive bodies. In the Soviet era scientists' studies, who investigated theoretical problems of public administration, there are positions on the identity of the concepts of public administration as an organizational executive and administrative

${ }^{6}$ Koval L.V. Administratyvne pravo Ukrainy: Kurslektsii. K.: Osnovy, 1998. 208 s. S. 116. (In Ukrainian).

${ }^{7}$ Administratyvna diialnist OVS. Zahalnachastyna: Pidruchnyk / Za zah. red. I.P. Holosnichenka, Ya.Iu. Kondratieva. K.: UAVS, 1995. 177 s. S. 6. (In Ukrainian).

${ }^{8}$ Administratyvna diialnist: Navchalnyi posibnyk / Zazah. red. dotsenta O.I. Ostapenka. Lviv: LIVS, 2002. 252 s. S. 5.(In Ukrainian).

${ }^{9}$ VedelZh. Admynystratyvnoe pravo Frantsyy. M.: Prohress, 1973. 512 s. S. 50-54. (In Russian).

${ }^{10}$ Zarosylo V.O. Porivnialnyi analiz administratyvnoi diialnosti militsii Ukrainy ta politsii zarubizhnykhkrain (Velykobrytanii, SShA, KanadytaFrantsii): Dys... k. yu. n. / 12.00.07. K.: Natsion. akademiiavnutr. sprav, 2002. 250 s. S. 13.(In Ukrainian). 
activity of state bodies and administrative activity ${ }^{11}$. Such views occur in Western European administrative and legal science. Thus, in German administrative law, administrative activity is defined as planned human activity aimed at achieving certain social goals ${ }^{12}$. And well-known specialist in management problems I. Chepel defines administrative activity as the process of achieving national goals through the activity of public administrations ${ }^{13}$.

Among Russian scholars, there is now a position according to which administrative activity is public administration in a narrow sense, that is, the activity of executive bodies, executive-administrative bodies of the state in the exercise of executive power at its various levels ${ }^{14}$. Such an understanding of administrative activity takes into account only its managerial nature, and therefore not fully, and what is more, does not accurately reflect the purpose of this type of activity. It is indisputable that in the course of administrative activity, in addition to the powers of administrative content, other powers of the executive authoritiesarealso exercised, such as such as administrative services, taxes or other mandatory fees, enforcement measures, including administrative penalties for offenders, etc.

The analysis of various literary sources shows that commonly the concept of administrative activity is used to characterize the specific type of activity of law enforcement agencies (police, police), which, in our opinion, does not significantly affect the nature of the activity, called administrative.

In the scientific literature devoted to the study of issues of organization and activity of law enforcement agencies, administrative activity is understood as the activity of the police, in the process of practical implementation of which (ie the police - note is mine) its apparatus, services, employees are guided by administrative law ${ }^{15}$. One of the first who formulated the definition of administrative action, linking it with certain police functions, was L.L. Popov. In his opinion, the administrative activity of the police is an activity related to the protection of order in public places, ensuring the safety of traffic and pedestrians, rules of using transport, with

${ }^{11}$ Lunev A.E. Teoretycheskye problemы hosudarstvennoho upravlenyia. M.: Nauka, 1974. 248 s. S. 8, 164. (In Russian).

${ }^{12}$ Admynystratyvnoe pravo zarubezhnыkh stran: Uchebnyk / Podred. A.N. Kozыryna y M.A. Shtatynoi. M.: Spark, 2003. 464 s. S. 31. (In Russian).

${ }^{13}$ Administrative management for development / Ed. by Y. Chapel. Brussel, 1947. 40 s. S. 40. (In Russian).

${ }^{14}$ Tykhomyrov Yu.A. Teoryiakompetentsyy. M.: Yurynformtsentr, 2001. 355 s. S. 157. (In Russian).

${ }^{15}$ Eropkyn M.Y., Popov L.L. Admynystratyvno-pravovaia okhrana obshchestvennoho poriadka. L.: Lenyzdat, 1973. 328 s. S. 101.(In Russian). 
observance of the passport system ${ }^{16}$. The authors of the textbook "Administrative activity of law enforcement agencies" define the administrative activity of law enforcement agencies as regulated by the rules of administrative law, their executive power aimed at ensuring the personal security of citizens, protecting their rights and freedoms, legitimate interests, public order, public security and combating offenses ${ }^{17}$. I.P. Golosnichenko continues to defend this position. ${ }^{18} \mathrm{~A}$ number of scientists define the administrative activity of law-enforcement bodies as specific, executiveadministrative, sub legislative, state-governmental activity consisting in the organization and implementation of public order protection, public safety, prevention and termination of crimes and other offenses ${ }^{19}$. Or as a purposeful, organizing, executive and administrative activity, which consists in the immediate, daily, practical implementation of tasks and functions in the sphere of internal affairs ${ }^{20}$.

These concepts of administrative activity somewhat limit the content of this activity and reduce it to providing the internal affairs bodies with the functions of protecting legal relations, in fact identifying it with law enforcement activity.

At the same time, the authors of these concepts, although they say that the police carries out law-enforcement administrative activity, but point to its servicing nature, recognizing it as a means of ensuring law enforcement activity $^{21}$.

Some element of novelty is given the definition of the analyzed concept contained in the glossary of terms and concepts of administrative activity, namely: the administrative activity of the police is an executive and administrative activity on the organization of work of subordinate services, employees and practical implementation of public order and protection

${ }^{16}$ Popov L. Ubezhdenye y prynuzhdenye. Orhanyzatsyonno-vospytatelnye y admynystratyvno-pravovye sredstva okhranы obshchestvennoh oporiadka $v$ deiatelnosty sovetskoi mylytsyy. M.: Moskovskyi rabochyi, 1968. 160 s. S. 5. (In Russian).

${ }^{17}$ Administratyvna diialnist OVS. Zahalna chastyna: Pidruchnyk / Zazah. red. I.P. Holosnichenka, Ya.Iu. Kondratieva. K.: UAVS, 1995. 177 s. S. 7.(In Ukrainian).

${ }^{18}$ Administratyvne pravo Ukrainy. Akademichnyi kurs: Pidruch.: U 2 t. / Red. kolehiia: V.B. Averianov (holova). K.: Yurydychnadumka, 2005. T. 2. Osoblyva chastyna. 624 s. S. 349. (In Ukrainian).

${ }_{19}$ Administratyvna diialnist: Navchalnyi posibnyk / Zazah. red. dotsenta O.I. Ostapenka. Lviv: LIVS, 2002. 252 s. S.8. (In Ukrainian).

${ }^{20}$ Admynystratyvnaia deiatelnost orhanov vnutrennykh del: Uchebnyk / Podred. dokt. yuryd. nauk, prof. A.P. Koreneva. M.: Moskovskyi un-t MVD Rossyy, yzd-vo «Shchyt-M», 2003. Chastobshchaia. 309 s. S. 38. (In Russian).

${ }^{21}$ Administratyvna diialnist OVS. Zahalnachastyna: Pidruchnyk / Zazah. red. I.P. Holosnichenka, Ya.Iu. Kondratieva. K.: UAVS, 1995. 177 s. S. 8. (InUkrainian). 
public safety by administrative and legal means ${ }^{22}$. This concept draws attention not only to the external but also to the internal orientation of the activity carried out by law enforcement agencies.

The most general definition of this concept can be considered as follows: administrative activity of law-enforcement bodies - a purposeful, organizing, executive and administrative activity, which consists in the direct, daily, practical implementation of tasks and functions of the state in the sphere of internal affairs ${ }^{23}$. This definition of administrative activity that, in our view, most fully and adequately reflects the content of this type of activity of law enforcement agencies. At the same time, it should be noted that in all the above positions, the content of the concept is invested by the activity of a special entity aimed at achieving the desired goal.

The analysis of legal acts regulating the activity of the bodies of revenue and duties, carrying out customs affairs, their officials and practice of application, shows that the administrative nature is the activity of many divisions of bodies of revenue and duties, which, in particular, covers the provision of the order of movement through the customs border of goods, objects and vehicles, the implementation of customs control and customs clearance of objects of movement, control over the movement across the customs border of goods containing objects of law and intellectual property, taking measures of tariff and non-tariff regulation when moving goods across the customs border, prevention and termination of customs offenses, etc.

In addition, the administrative and legal means used by officials of the revenue and duties authoritiesarewidely used in the process of creating favorable conditions for accelerating trade and passenger traffic across the customs border, verification of certificates of origin of goods.

Thus, on the one hand, the administrative activity of the revenue and duties authorities cover law-making and individual-administrative activity aimed at positive regulation of public relations in the customs and legal sphere in accordance with the rules of laws and other normative acts. Components of administrative activity for this purpose are:

- sub-legislative normative regulation of public relations is carried out by issuing (adopting) revenue and duties authorities of sub-normative acts aimed at establishing general rules for an indefinite number of

\footnotetext{
${ }^{22}$ Borodyn S.S., Yvanov P.V., Oskyn F.F. Admynystratyvnaia deiatelnost orhanov vnutrennykh del: Slovartermynov y poniatyi. SPb.: Lan, 2000. 240 s. S. 6. (In Russian).

${ }^{23}$ Admynystratyvnaia deiatelnost orhanov vnutrennykh del: Uchebnyk / Podred. dokt. yuryd. nauk, prof. A.P. Koreneva. M.: Moskovskyi un-t MVD Rossyy, yzd-vo «Shchyt-M», 2003. Chastobshchaia. 309 s. S. 38. (In Russian).
} 
people in accordance with the laws and legal acts of other public administration bodies;

- individual regulation of public relations in accordance with the laws and legal acts of other public administration bodies, which is carried out by issuing (adopting) revenue and duties authorities regulatory legal acts and performing administrative actions in relation to individually defined entities (citizens, business entities), aimed at establishing, changing and termination of their rights and obligations.

On the other hand, the administrative activity of the revenue and duties authorities is aimed at preventing the commission of violations of customs rules, their detection and termination, to ensure the customs security of the state and protection of society. For this purpose, the revenue and duties authorities, in carrying out this activity, do not manage the subjects of moving, do not regulate their behavior, but provide security and protection of the rights and legitimate interests of citizens and the state in general from unlawful encroachments, from violations by individual subjects of moving.At its core, this activity has a protective nature

Thus, the administrative activity of the revenue and duties authorities in this sense is in fact one of the main directions of protecting the economic interests of Ukraine, creating favorable conditions for the development of its economy, protecting the rights and interests of citizens and business entities, preventing and suppressing illegal actions, and applying to offenders measures of administrative procedural support and administrative penalties.

The duality of its nature consists in existence of these two sides of the administrative activity of the revenue and duties authorities: carrying out public administration in the customs legal sphere, the of revenue and duties authorities at the same time and first of all must ensure compliance with the rule of law and order in it.Awareness of such heterogeneity of administrative activity allows to speak about existence of several of its directions.

In the light of the above, the problem of the functional purpose of the revenue and dutiesauthority'sadministrative activity is relevant. The revenue and dutiesauthority's activity should provide not rather a power-organizing influence on public relations in the customs sphere, but as promote the fullest possible enjoyment of rights and legal interests by citizens and economic operators in this spheres far as their effective protection in case of any violations, both within the state and abroad.Therefore, we should agree with the opinion of V.B. Averyanov, who believed that the activity of state institutions should be a subject to needs of enjoyment of human rights and freedoms, ensuring their priority over all other values of a democratic, 
welfare,rule-of-law state ${ }^{24}$. From his point of view, such a restructuring of the state institutions activity requires the replacement of the ideology of "domination" of the state over a man to the opposite one - the ideology of "serving" of the state to the interests of man.

\section{Basic features of the administrative activity}

The wording of the concept of administrative activity of the revenue and duties authorities requires clarification of the question regarding the signs of this specific type of activity, in other words, those features that individualize this phenomenon.

This approach also allows us to characterize the goal-setting of administrative activity in its scope - from the preparation and adoption of legal norms to itsimplementation using security mechanisms. In our opinion, the administrative activity carried out by the revenue and duties authorities is characterized by the following characteristics.

Administrative activity is a special type of activity related to the exercise of the state executive power in the field of customs legal regulation of public relations, which differs from the activity in the implementation of the legislative and judicial power by its content, form and methods.This is what is crucial for understanding the essence of this type of activity and conditions the existence of all other signs.

State-power nature of administrative activity is a type of activity which is prerogatives of the relevant competent authorities of the state - the revenue and duties authorities. Its implementation is ensured by the totality of state funds of economic and political, social and ideological, encouraging and coercive nature.State-power point is its essential feature, allowing to perform an effective means in management of public relations. The revenue and duties authorities shall exercise their powers in an official manner on behalf of the state within the competence clearly defined by law.They are empowered to monitor compliance with the established rules in the customs sphere, to give legal evaluation of doings and actions of citizens and economic operators, to identify violations and to respond on them in accordance with the procedure established by law, and also to make binding orders within their competence and to impose the same mandatory requirements, to apply compulsory measures in cases and forms provided for by law.

${ }^{24}$ Averianov V. Administratyvna reforma i pravova nauka. Pravo Ukrainy. 2002. № 3. S. 20-30. S. 25. (In Ukrainian). 
The publicity of administrative activity consists in the fact that it is carried out not to satisfy the private, personal needs of those whom it relies on, but in the interests of "one and all."

Protecting the economic interests of Ukraine, taking measures to protect the interests of consumers of goods, counteracting customs offenses, the revenue and duties authorities carry out administrative activity for the benefit of all. Thus, the right of the citizen corresponds to the duty of the revenue and duties authorities to create favorable conditions for the exercise of his right to move goods, objects, vehicles through the customs border of the state.

Administrative activity of the revenue and duties authorities is sub legislative. It is carried out on the basis and for the implementation of laws and other legal acts in the exact conformity and within the limits specified by the law, using appropriate legal means. The cited feature of administrative activity is very important and relevant, because the scope of the latter is quite broad. The activity of the revenue and duties authorities is carried out in constant interaction with citizens, subjects of foreign economic relations, other state bodies of Ukraine and foreign states, as well as with international organizations, and any deviation from the requirements of the law can cause significant damage to their rights and interests, complicate their own activity. In the process of this activity, unlawful actions of officials of the revenue and duties authorities,as well as opposition of legality and expediency are unacceptable.

The legality of administrative activity is also important because, in the course of thisactivity, the law is primarily implemented. The application of the rules of law by officials is conditioned by the solution of specific life situations and certain circumstances.

Legal subordination of administrative activity is also important because, in the course of this activity, the legal prescriptions are primarily implemented. Application of law by officials is conditioned by the solution of specific life situations and certain circumstances. For example, officials of revenue and duties authorities can make direct orders (for example, to establish additional requirements for the arrangement of temporary storage warehouses) or to take actions the content of which is to comply with the direct prescriptions of law (for example, verification of documents and information required for customs formalities).

In the process of implementing administrative activity, the competent revenue and duties authoritiesdevelop and issue sectorial regulatory acts. The rules contained therein are subordinate in nature, since these acts are adopted to comply with the requirements of the law, their specification and detail. 
In addition, the revenue and duties authoritiesareempowered to carry out activityrelated to the prosecution of violators of customs legislation and to apply compulsory measures to them independently. Undoubtedly, thisactivityshould be implemented in full compliance with the requirements of the law.

Administrative activityhas an executive and administrative character. Its main purpose is to fulfill the requirements of the current national legislation and obligations stipulated by the international treaties of Ukraine on matters within the competence of the revenue and duties authorities, that is, the practical implementation of laws and other normative acts. At the same time, for the successful and effective performance of their executive functions, they are vested with administrative powers, which provide for the ability to subordinate the objects of management of its subject.As a consequence, the relations that arise in the process of this activity are relations of subordination, powerorganizing, managing.Without the necessary administrative powers, it is almost impossible to achieve the goal of fulfilling the law and other normative acts, the day-to-day management of subordinate to the revenue and duties authorities' activity and the solution of other tasks facing SFS of Ukraine.The revenue and duties authorities issue regulations containing regulations or individual regulations, and apply coercive measures.

The administrative activity of the revenue and duties authorities covers both law-making and law-enforcement activity. The law-making activity of the revenue and duties authorities is reflected in issuing sectorial regulations governing the various relations that arise in the implementation of customs policy within the scope of its competence.

Law enforcement activity of the revenue and duties authorities consists in organizing and practically implementing the requirements of customs regulations regarding specific life cases or individually defined persons, protection and defense these standards from any violations, applying coercive measures, ensuring the execution of punishment, as well as taking preventive measures.Although, after the formation of the SCS of Ukraine and its functional subordination to the Ministry of Finance of Ukraine, law-making activity was substantially restricted, the revenue and duties authoritiesare still empowered with normative-making powers.

The activity of the revenue and fees authoritiesis a kind of organizational activity of the bodies of executive power. The organizational essence of administrative activity is manifested in the fact that in the process of its implementation joint purposeful activity of interested parties regarding solving problems in the field of customs and legal regulation of public 
relationsis organized, regulated, coordinated, in particular: issues related to the protection of national economic interests are resolving, the activityof subjects of foreign economic activity are streamlining, their right to move goods, items and vehicles across the customs border is ensured, the functioning of the SCS is maintained, international customs cooperation is carrying out.On this basis, a general state of ordering of subjects and objects of management, relations between them is created.Notably, that in the process of this activity the achievement of certain tasks is achieved on the scale of the whole society, and not only within the framework of a separate collective, a separate community of people.We must agree with the opinion of I. Sabo, who notes that in this context such activity of the state can be called transforming activity: it turns economic and other social relations into general legal relations, which are subsequently fixed in the rules in order to influence social relations turning them into legal ones. ${ }^{25}$ At the same time, administrative activity is not limited to a meaningless form, which provides stability, strength, guarantee of social, economic, political content.

In the field of customs and legal regulation, special actions which have been deliberately designed both in form and contentare being taken: shipping documents are checked, permits are issued, legal acts issued, etc.All these actions affect the behavior of participants in customs and legal relations, contributing to the most expedient and usefulfrom the point of view of society and the state, achievement of socially useful goals. This is the reason for the socially significant role of administrative activity - promoting the achievement of the public good by reconciling individual, group, public and state interests. In this sense, activity of the revenue and duties authorities should cause certain practical changes in social life, which allows recognizing it as a practical activity that has a positive socio-legal value.

Continuity, constancy and regularity of administrative activity. This feature is based on historical experience and objective laws governing the functioning of the system of the revenue and duties authorities, the main purpose of which is the direct implementation of the customs policy as part of a single national policy.In the process of the researched activity, problems are solved and the functions of the state are realized, protection of both the interests of the state and the constitutional rights and interests of citizens, as well as business entities is ensured.

Processualization of administrative activity that is a normatively regulated system of the revenue and duties authorities' actions and operations, which are consistently carried out by the bodies and their

${ }^{25}$ Sabo Y. Osnov yteoryy prava. M.: Yurydycheskaia lyteratura, 1974. 387 s. S. 74. (In Russian). 
officials, in the established procedural forms. Procedural regulation of administrative activity is the most important guarantee of ensuring the rule of law in the broadest sense of the term and an effective way of ensuring the rights and legitimate interests of citizens and economic entities. However, it should not be forgotten that administrative activity is not exclusively of a legal nature, because it consists of legal and non-legal (organizational, factual) parts.In other words, not all revenue and duties authorities' actions entail legally significant consequences.And if the legal part of the activityof the revenue and duties authorities is sufficiently detailed and clearly regulated by the rules of law, then the rest of it is subject to regulation only in general form.Within the framework of general norms on rights and obligations and separate starting procedural rules (for example, time limits), the official of the revenue and duties authoritiesindependently and creatively chooses ways and forms of solving the tasks.

Relations that arise in the process of administrative activity can be separated into two groups: relations directly related to the formation and implementation of customs policy of the state, ether implementation of executive power, and other relations, including internal organizational processes that arise in the process of formation and functioning of the system ofthe revenue and duties authorities.The priority of the relations of the first group is obvious, because the system of the SFS of Ukraine exists not for the satisfaction of its own interests, but for functioning within its purpose.

The certifying and search nature of administrative activity consists in the fact that the revenue and duties authorities forthe fulfilling their tasks and functions must collect, accumulate, analyze, officially confirm, register (certify), draw up information that will allow legitimate and justified decision to be performed.

The administrative activity of the revenue and duties authorities is characterized by a rational combination of centralized management with direct (operational) management.Centralized management is reflected in the definition of priority areas of activity (for example, in the Strategic Initiatives for the development of the SFS until $2020^{26}$, the establishment of general rules, regulations, etc.Direct (on-going) management is characterized by the existence of direct links between the higher revenue and duties authorities and their subordinates.Both management and governance are carried out using vertical (subordinate, hierarchical) or horizontal links and relations in the SCS of Ukraine.

\footnotetext{
${ }^{26}$ Stratehichni initsiatyvy rozvytku DFS do 2020 r. URL: http://sfs.gov.ua/mediatsentr/novini/322784.html (In Ukrainian).
} 
The presence of this sign improves the quality and efficiency of the realization by the revenue and duties authorities of their powers, enhances their responsibility for the failure or improper performance of their duties.On the other hand, state and local authorities are obliged to create conditions for the proper functioning of the revenue and duties authorities and assist them in performance of tasks and functions.

The administrative activity of revenue and duties authorities is carried out with a help of various means, methods and techniques - methods of activity which are externally reflected in specific actions of various nature, which are carried out within their competence and cause certain consequences - forms of activity. In the administrative-legal literature, these methods and forms of activity of executive bodies, and consequently, of the revenue and duties authorities, were called administrative-legal ${ }^{27}$, influence on social relations is exercised with their use.

One of the peculiarities of the administrative activity of the revenue and duties authoritiesis its preventive orientation, which is provided by such organization of work of all bodies, divisions, individual officials, forces and means that would create effective conditions for the existence of civilized relations connected with the movement of goods, objects and vehicles across the customs border, strict compliance with customs legislation and prevention of its violations.Success in this work is achieved only after a deep and complete analysis of the own activityat the present stage and determination of its priorities in the future, analysis of the current regulatory framework and the practice of its application by citizens and business entities, identification of the causes and conditions conducive to the commission of customs offenses.In this context, ensuring openness and transparency of the SCS of Ukraine for the public is essential.This can be realized by bringing information about the main results of the activityof the revenue and tax authorities, the general situation in this area through the media or during speeches or messages of the leaders of the SCS of Ukraine. Administrative activityis professional in nature.

Professionalism is an important feature of the researched activity. The professional nature of administrative activity is due to the fact that specialized activity requires from those who carry out it, relevant professional knowledge (law, economics, psychology) and certain skills. Taking into account that the administrative activityis coercive, it requires from those who carry it out, a good knowledge of the business, reasonable,

${ }^{27}$ Admynystratyvnoe pravo / Pod red. prof. Yu.M. Kozlova y prof. L.L. Popova. M.: Yurystъ, 1998. 728 s. S. 255. (In Russian). 
competently use of compulsion, because the baseless use of coercive measures can be regarded as an abuse of power, will cause dissatisfaction of citizens and business entities and generate conflicts.As a result, this professional activity is carried out by specially trained public servants, they are competent, which means they can effectively protect the economic interests of the state, the rights and legitimate interests of citizens and business entities in the customs sphere.

Considered signs of the administrative activityof the revenue and duties authorities, do not characterize some of its sides or aspectsin particular, butin complex as a whole phenomenon that consists of interdependent and interrelated parts.The diverse relationships and relations that arise between these components, and the properties generated by them, which define them as a system, ensure the existence of relatively independent laws of the development and functioning of administrative activity.

Considering the heterogeneity of social relations in the field of customs and legal regulation, which are conditioned by the complex nature of modern customs legislation, it should be noted that the administrative activity of the revenue and duties authorities is regulated by the norms of several branches of law: customs, financial, tax, but administrative rules are still dominant (including its procedural component).Why administrative rather than customs? First, it is worth noting that there is still no common view among the scholars regardinga sectorial nature of customs law.

Some jurists consider customs law to be an institution of administrative law $^{28}$ or its subsector, ${ }^{29}$ others recognize customs law as an independent branch of law $^{30}$ or its special industry ${ }^{31}$, however, the vast majority classifies it as complex industries ${ }^{32}$. There is an opinion that it can only be

${ }^{28}$ Belskyi K.S. Polytseiskoe pravo: Lektsyonnui kurs. M.: DYS, 2004. 815 s. (In Russian).S.463. (In Russian).

${ }^{29}$ Komziuk V.T. Administratyvno-pravovi zasady zdiisnennia mytnoi spravy: poniattia ta vydy. Visnyk Natsion. un-tu vnutrishnikhs prav. 2003. № 2. S. 189-194. S. 192. (In Ukrainian); Sandrovskyi K.K. Tamozhennoe pravo. K.: Vyshchashkola, 1974. 176 s. S. 19. (In Ukrainian).

${ }^{30}$ Tamozhennoe pravo: Uchebnyk dlia vuzov / M.M. Rassolov, N.D. Эryashvyly, V.N. Haluzo y dr.; Podred. M.M. Rassolova, N.D. Эryashvyly. M.: YuNYTY-DANA, 2005. 384 s. S. 11. (In Russian).

${ }^{31}$ Kornieva T. Mytne pravo ya ksamostiina spetsialna haluz prava. Pidpryiemnytstvo, hospodarstvo i pravo. 2005. № 9. S. 3-5. S. 5. (InUkrainian).

${ }^{32}$ Dorofieieva L.M., Yasevych M.M. MytnepravoUkrainy: navchalnyi posibnyk. Uzhhorod: PP Bereza, 2013. 268 s. S. 11. (In Ukrainian); Kormych B.A. Tamozhennoe pravo. Odesskaia shkola prava. Vvedenye v ukraynskoe pravo. / S. V. Kyvalov, N.V. Anyshchuk, T.A. Ostapenko; podobshch. red. S.V. Kyvalova. 3-e yzd. Odesa: Yurydychnaliteratura, 2016. 504 s. S. 412. (In Ukrainian); Mytnepravo Ukrainy: navchalnyi posibnyk / Za zah red. V.V. Chentsova. D.V. Pryimachenka / 2-e vyd. K.: Istyna, 2008. 328 s. S. 12. (InUkrainian). 
said about customs legislation, that is, legislation on customs ${ }^{33}$. Secondly, almost unanimously, scientists recognize that the subject of customs law regulation is a wide range of public relations, which are regulated by the norms of various branches of law, such as administrative, financial, civil, criminal, labor, etc.However, this complex of social relations, although it is heterogeneous, is nevertheless integrated with the help of such a systemforming factor as the movement of goods, objects and vehicles across the customs border into a specific set - customs relations. Third, the vast majority of these public relations, to which the revenue and dutiesauthoritiesand their officials are involved, are related to the movement of goods, objects and vehicles across the customs border, the implementation of customs procedures, the establishment of customs regimes, the legal status of the revenue and duties authorities.All these relations are of a managerial, organizational nature and, as a whole, are covered by administrative legal regulation, and therefore are regulated by the norms of administrative and administrative-procedural law. The dominance of administrative and administrative procedural norms in the process of regulating public relations in the customs sphere is recognized by such wellknown specialists in the field of customs law as M.G. Schulga ${ }^{34}$. The norms of substantive administrative law regulate relations associated with the establishment of the procedure for moving goods, objects and vehicles across the customs border, customs control, customs clearance, customs statistics, liability for violation of customs rules, types of penalties, legal status of the revenue and duties authorities, etc. The administrativeprocedural nature of the rules governing the implementation of customs procedures, proceedings on cases of violation of customs rules. The rules governing the implementation of customs procedures, proceedings on cases of violation of customs rules are administrative-procedural by their nature.

Fourth,the revenue and duties authoritiesare type of executive bodies, which carry out state-power management activity, traditionally associated with administrative law on behalf of the state.Considering that the revenue and dutiesauthoritiesas executive bodies are mandatory participants in customs legal relations, it can be argued that their activityis governed by administrative law.

${ }^{33}$ BakaevaO.Iu., Matvyenko H.V. Tamozhennoe pravo Rossyy: Uchebnyk / Otv. red. N.Y. Khymycheva. M.: Yurystъ, 2004. 427 s. S. 27. (In Russian); Kozyrin A.N. Pravovoe rehulyrovanye tamozhenno-taryfnoho mekhanyzma (sravnytelno-pravovoe yssledovanye): Avtoref. dys. ... dokt. yuryd. nauk. M.: MHYMO MYD RF, 1994. 53 s. S. 19. (In Russian).

${ }^{34}$ Shulha M.H. Poniattia mytnoho prava. Problemy zakonnosti: Resp. mizhvidomch. nauk. zb. / Vidp. red. V.Ia. Tatsii. X.: Natsion. yuryd. akad. Ukrainy, 2000. Vyp. 42. S. 124-130. S. 127. (In Ukrainian). 


\section{CONCLUSIONS}

Thus, taking into account the above-mentioned signs of administrative activity and the specifics of the sphere of customs and legal regulation of public relations, we can formulate the following definition of the concept of administrative activity of the revenue and dutiesauthorities executing customs affairs: administrative activity of the revenue and dutiesauthoritiesis a regulated mainly by administrative law norms, bylaws, purposeful, state-power, executive and administrative activity related to the practical implementation of measures aimed at the direct implementation of the state customs policy, and the organization and functioning of the system of revenue and duties.

A theoretical study of the administrative activity of the public administration bodies that directly carry out customs affairs is particularly relevant in connection with the permanent reorganization of the existing system of national customs administration, improvement of the legal regulation of its organization and functioning and bringing it into line with international standards.

\section{SUMMARY}

The article deals with development of Ukraine as a social, legal state is directly related to increasing of public administration effectiveness, which is aimed at ensuring the sustainable development of society, timely identification, prevention and neutralization of real and potential threats to national interests in all areas of public life without exception. Ensuring an adequate level of national security of the state that meets the requirements of the present is one of the most important functions of the state. Public administration bodies are involved in the implementation of this function. Important role in ensuring national security belongs to the revenue and duties authorities, whose tasks and functions are aimed at protecting the national interests and rights of citizens and economic entities in the field of customs law regulation.

In the process of carrying out their tasks and functions, the revenue and duty authorities actively use various in nature, forms and methods means and approaches of influence on public relations in order to regulate it. Among this set of means, we can single out, as they are defined in the legal literature, administrative legal means. The practical implementation of administrative remedies is carried out within the framework of activity, which has been called administrative in the legal literature.

As a result of the scientific research, the notion of administrative activity of the bodies of revenue and duty was formulated, its main features were 
identified and characterized. Thus, the administrative activity of the revenue and duty bodies carrying out customs affair is mainly regulated by the rules of administrative law, legislative, purposeful, state-power, executiveadministrative activity, related to the practical implementation of measures aimed at the direct implementation of customs policy of the state and the organization and operation of the system of revenue and duty.

\section{REFERENCES}

1. Pro Ministerstvo dokhodiv i zboriv: Ukaz Prezydenta Ukrainy vid 18.03.2013 r. № 141/2013 OfitsiinyivisnykUkrainy. 2013. № 22. St. 739. (In Ukrainian).

2. Pro utvorennia Derzhavnoi fiskalnoi sluzhby Ukrainy: Postanova Kabinetu Ministriv Ukrainy vid 21 travnia 2014 r. № 160. OfitsiinyivisnykUkrainy. 2014. № 46. St. 1213. (In Ukrainian).

3. Pro utvorennia derzhavnoi podatkovoi sluzhby Ukrainy ta Derzhavnoi mytnoi sluzhbyU krainy: Postanova Kabinetu Ministriv Ukrainy vid 18 hrudnia 2018 r. № 1200. Ofitsiinyi visnyk Ukrainy. 2019. № 7. St. 208. (In Ukrainian).

4. Pryimachenko D.V. Administratyvna diialnist mytnykh orhaniv: problemy teorii ta praktyky: Monohrafiia. Dnipropetrovsk: AMSU, 2007. 290 s. (In Ukrainian).

5. Petrov H.Y. Pooshchrenye $v$ hosudarstvennom upravlenyy. Yaroslavl: Yzd-voYaroslavskoho un-ta, 1983. 219 s. (In Russian).

6. Koval L.V. Administratyvne pravo Ukrainy: Kurslektsii. K.: Osnovy, 1998. 208 s. (In Ukrainian).

7. Administratyvna diialnist OVS. Zahalna chastyna: Pidruchnyk / Za zah. red. I.P. Holosnichenka, Ya.Iu. Kondratieva. K.: UAVS, 1995. 177 s. (In Ukrainian).

8. Administratyvna diialnist: Navchalnyi posibnyk / Za zah. red. dotsenta O.I. Ostapenka. Lviv: LIVS, 2002. 252 s. (In Ukrainian).

9. VedelZh. AdmynystratyvnoepravoFrantsyy. M.: Prohress, 1973. 512 s. (In Russian).

10.Zarosylo V.O. Porivnialnyi analiz administratyvnoi diialnosti militsii Ukrainy ta politsii zarubizhnykh krain (Velykobrytanii, SShA, Kanady ta Frantsii): Dys... k. yu. n. / 12.00.07. K.: Natsion. akademiia vnutr. sprav, 2002. 250 s. (In Ukrainian).

11.Lunev A.E. Teoretycheskye problemb hosudarstvennoho upravlenyia. M.: Nauka, 1974. 248 s. (In Russian).

12. Admynystratyvnoe pravo zarubezhnыkh stran: Uchebnyk / Pod red. A.N. Kozyryna y M.A. Shtatynoi. M.: Spark, 2003. 464 s. (In Russian). 
13. Administrative management for development / Ed. by Y. Chapel. Brussel, 1947. 40 s. (In Russian).

14. Tykhomyrov Yu.A. Teoryia kompetentsyy. M.: Yurynformtsentr, 2001. 355 s. (In Russian).

15.Eropkyn M.Y., Popov L.L. Admynystratyvno-pravovaia okhrana obshchestvennoho poriadka. L.: Lenyzdat, 1973. 328 s. (In Russian).

16. Popov L. Ubezhdenye y prynuzhdenye. Orhany zatsyonnovospytatelnye y admynystratyvno-pravovye sredstva okhranы obshchestvennoho poriadka $\mathrm{v}$ deiatelnosty sovetskoi mylytsyy. M.: Moskovskyi rabochyi, 1968. 160 s. (In Russian).

17. Administratyvne pravo Ukrainy. Akademichnyi kurs: Pidruch.: U 2 t. / Red. kolehiia: V.B. Averianov (holova). K.: Yurydychna dumka, 2005. T. 2. Osoblyva chastyna. 624 s. (In Ukrainian).

18. Admynystratyvnaia deiatelnost orhanov vnutrennykh del: Uchebnyk / Podred. dokt. yuryd. nauk, prof. A.P. Koreneva. M.: Moskovskyi un-t MVD Rossyy, yzd-vo «Shchyt-M», 2003. Chastobshchaia. 309 s. (In Russian).

19. Borodyn S.S., Yvanov P.V., Oskyn F.F. Admynystratyvnaia deiatelnost orhanov vnutrennykh del: Slovar termynov y poniatyi. SPb.: Lan, 2000. 240 s. (In Russian).

20. Averianov V. Administratyvna reforma i pravova nauka. Pravo Ukrainy. 2002. № 3. S. 20-30. (In Ukrainian).

21. Sabo Y. Osnovy teoryy prava. M.: Yurydycheskaia lyteratura, 1974. 387 s. (In Russian).

22. Stratehichni initsiatyvy rozvytku DFS do 2020 r. URL: http://sfs.gov.ua/media-tsentr/novini/322784.html (InUkrainian).

23. Admynystratyvnoe pravo / Podred. prof. Yu.M. Kozlova y prof. L.L. Popova. M.: Yurystъ, 1998. 728 s. (In Russian).

24. Belskyi K.S. Polytseiskoe pravo: Lektsyonnyi kurs. M.: DYS, 2004. 815 s. (In Russian).

25. Komziuk V.T. Administratyvno-pravovi zasady zdiisnennia mytnoi spravy: poniattia ta vydy. Visnyk Natsion. un-tu vnutrishnikh sprav. 2003. № 2. S. 189-194. (InUkrainian).

26. Sandrovskyi K.K. Tamozhennoe pravo. K.: Vyshcha shkola, 1974. 176 s. (InUkrainian).

27. Tamozhennoe pravo: Uchebnyk dlia vuzov / M.M. Rassolov, N.D. Eryashvyly, V.N. Haluzo y dr.; Podred. M.M. Rassolova, N.D. Eryashvyly. M.: YuNYTY-DANA, 2005. 384 s. (In Russian).

28. Kornieva T. Mytne pravo yak samostiina spetsialna haluz prava. Pidpryiemnytstvo, hospodarstvo i pravo. 2005. № 9. S. 3-5. (In Ukrainian). 
29. Dorofieieva L.M., Yasevych M.M. Mytne pravo Ukrainy: navchalnyi posibnyk. Uzhhorod: PP Bereza, 2013. 268 s. (In Ukrainian).

30.Kormych B.A. Tamozhennoe pravo. Odesskaia shkola prava. Vvedenye v ukraynskoe pravo. / S. V. Kyvalov, N.V. Anyshchuk, T.A. Ostapenko; podobshch. red. S.V. Kyvalova. 3-e yzd. Odesa: Yurydychna literatura, 2016. 504 s. (InUkrainian).

31. Mytne pravo Ukrainy: navchalnyi posibnyk / Za zah red. V.V. Chentsova, D.V. Pryimachenka / 2-e vyd. K.: Istyna, 2008. 328 s. (In Ukrainian).

32. Bakaeva O.Iu., Matvyenko H.V. Tamozhennoe pravo Rossyy: Uchebnyk / Otv. red. N.Y. Khymycheva. M.: Yurystъ, 2004. 427 s. (In Russian).

33.Kozy rin A.N. Pravovoe rehulyrovanye tamozhenno-taryfnoho mekhanyzma (sravnytelno-pravovoe yssledovanye): Avtoref. dys. ... dokt. yuryd. nauk. M.: MHYMO MYD RF, 1994. 53 s. (In Russian).

34. Shulha M.H. Poniattia mytnoho prava. Problemy zakonnosti: Resp. mizhvidomch. nauk. zb. / Vidp. red. V.Ia. Tatsii. X.: Natsion. yuryd. akad. Ukrainy, 2000. Vyp. 42. S. 124-130. (In Ukrainian).

\section{Informationaboutthe author:} Pryimachenko D. V., Doctor of Law, Vice-Rector on Scientific Work of the University of Customs and Finance 2/4, Vernadsky str., Dnipro, 49000, Ukraine 